\section{The course of true science}

Investigative Pathways: Patterns

and Stages in the Careers of

Experimental Scientists

by Frederic Lawrence Holmes

Yale University Press: 2004. 288 pp. \$35, $£ 25$

\section{Robert Olby}

Recollections can be vivid, as when Francis Crick looked back to a moment in February 1953: "Jerry Donohue and Jim Watson were by the blackboard and I was by my desk, and we suddenly thought, 'Well, perhaps we could explain 1:1 ratios by pairing the bases.' It seemed too good to be true." Was this one of those 'eureka' moments, like August Kekulés vision on the Clapham omnibus of a snake biting its tail, that led him to propose the ring structure of benzene? Should we take these personal recollections for gospel, or seek out the written record, pour over the research notebooks for the embryo of the revelation, the stages in its almost subconscious formulation?

This and other questions concerning the career of the experimental scientist are raised and discussed by eminent science historian Larry Holmes in Investigative Pathways. Written shortly before his death, this brief book offers his reflections on 45 years of research into the careers of outstandingly successful experimental scientists, such as Claude Bernard, Antoine-Laurent Lavoisier and, most recently, Seymour Benzer. Holmes also looks back on his detailed study of the famous experiment by Matthew Meselson and Franklin Stahl on the semi-conservative replication of DNA. As well as mining his own intimate knowledge of these scientists, Holmes draws on the scholarly researches

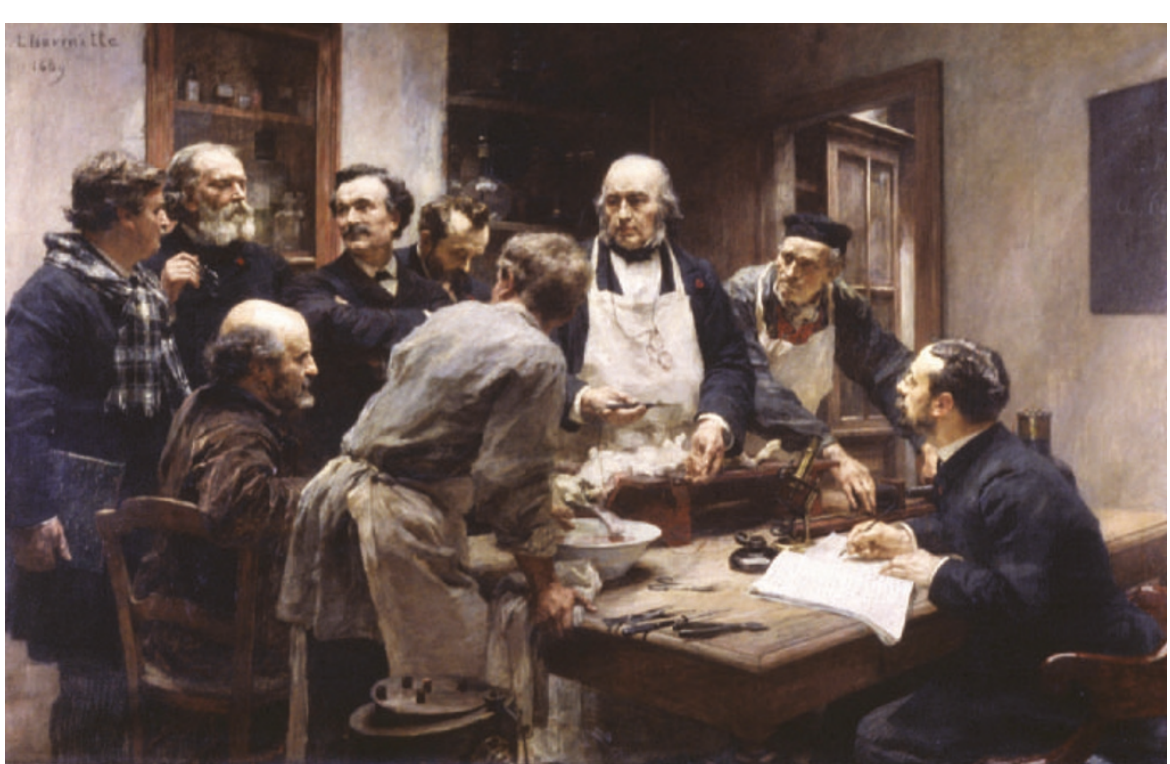

Life in the lab: Claude Bernard (third from right) teaching, in a painting by Leon L'hermitte.

of David Gooding on Michael Faraday, of Martin Rudwick on the geological'Devonian controversy', of Gerald Geison on Louis Pasteur, and of Nicolas Rasmussen on the electron microscope.

This book is no mild valedictory. Rather, Holmes seeks to persuade us that his concept of the investigative pathway provides the framework within which to view the research careers of these scientists. The great experiments, discoveries and eureka moments do exist, but are the nodal points in the investigative pathway. This pathway has a continuity that survives the surprises that nature throws at us. Yes, the experimental system is an important element in the story. Sometimes it takes the lead, redirecting the researcher, but it rarely lifts him out of the pathway being investigated. Even the belated recognition that the ribosome is not the message did not throw research into protein synthesis off course, for example. But such events serve to warn us against teleological reconstructions of the past in which it is assumed that the end point finally reached was envisaged from the start.

Holmes' intimate knowledge of the research careers of his subjects is clearly apparent. This book serves admirably to introduce the reader to his many studies and those of his colleagues in the field. For the biographer he offers insights into such topics as mentoring, creativity, the difficulty of remaining at the forefront as a scientific field matures, and the problems of ageing for the eminent scientist. Holmes is no anthropologist bereft of scientific knowledge coming to the lab to report on the strange society within, but a scholar who has devoted his life to understanding what goes on there.

Fashions in historiography come and go but Holmes, while absorbing what is valuable in each, has remained true to the calling he felt from the beginning: to seek to under- stand the stepwise generation of scientific concepts in the experimental life of the scientist. Departing in significant ways from other researchers, such as Thomas S. Kuhn, from the Edinburgh school of the sociology of knowledge and from the ethnomethodologists, Holmes found that the investigative pathway provided him with the best framework in which to place his detailed historical accounts. It expressed, he felt, the "distinctiveness and continuity of the individual scientific personality".

Comparing the metaphor of the path to Howard Gruber's 'network of enterprise' and Gooding's 'experimenter's space', Holmes admitted that his investigative pathway would be difficult to apply where the scientist engages in several research topics and moves back and forth from one to another, or leads a team of researchers. Confining his chosen cases to those in which his subjects worked alone and did not make such shifts, or to episodes in a scientist's life when he worked in this way, has enabled Holmes to exploit the pathway metaphor effectively.

Historians and scientists will find this little book both stimulating and informative. It will surely join that select group of classics that long outlive their authors.

Robert Olby is in the Department of the History and Philosophy of Science, University of

Pittsburgh, Pittsburgh, Pennsylvania 15260, USA.

\section{A struggle for order}

\section{A Well-Ordered Thing: Dmitrii \\ Mendeleev and the Shadow of the Periodic Table \\ by Michael D. Gordin}

Basic Books: 2004. 336 pp. \$30, £22.50

\section{Bernadette Bensaude-Vincent}

The name of Dmitrii Mendeleev is forever associated with the periodic table, which is found in chemistry laboratories and classrooms around the world. Yet this famous invention, which made sense and order out of the elements, was just one of Mendeleev's numerous achievements. Michael Gordin, an assistant professor of history at the University of Princeton, has reconstructed Mendeleev's heterogeneous career in all its facets and with all its contradictions. His book, $A$ Well-Ordered Thing, is neither a standard scientific biography nor an attempt to demystify this scientist, who became a national icon in Russia. Rather, Gordin uses Mendeleev as an example to explore the life and work of members of the educated élite in the nineteenth century in imperial St Petersburg.

Historians of chemistry might well feel a bit frustrated because there is little chemistry in this book. The need for a means of teaching chemistry was crucial to the 


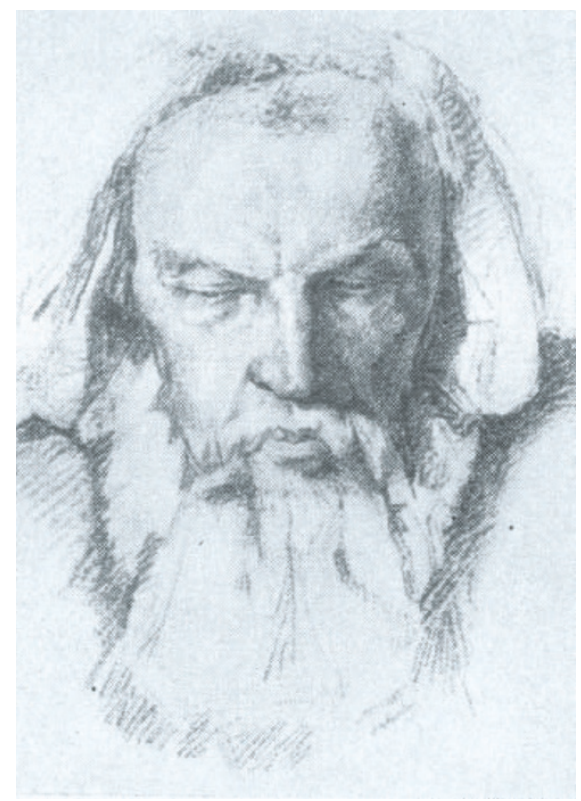

Dmitrii Mendeleev's periodic table was in tune with imperial Russia's desire for social order.

creation of the periodic system, so Gordin might have done well to give more attention to Mendeleev's textbooks. His 1861 organicchemistry textbook is dealt with too hastily, with the excuse that it was quickly eclipsed by Aleksandr Butlerov's book. And Mendeleev's successful Principles of Chemistry could have been analysed against the background of the tradition of university textbooks. Gordin also provides no details about earlier attempts at classification, or about how the periodic system was received either in Russia or abroad.

But the history of chemistry is not Gordin's main focus. Instead he attempts to understand the cultural impact of the major reforms and political upheavals that occurred in imperial Russia before the end of the nineteenth century. From this perspective, Mendeleev's periodic system appears as a metaphor underlying a programme for restructuring and modernizing tsarist Russia. The periodic law, with its predictions of unknown elements and bold corrections of atomic weights, was one expression of an irrepressible attempt to eradicate misfits and anomalies in various domains.

This long-standing quest for order contrasts with Mendeleev's versatility. Although for today's chemists he embodies the chemistry of the elements, he did not spend much time on this topic. He abandoned his research on elements soon after constructing the periodic table, despite uncertainties about the classification of rare-earth elements and rare gases. In the 1870s he initiated a project that was his age's equivalent of 'big science' because it involved high-pressure devices. His objective was to investigate deviations from the ideal gas law with the expectation of isolating ether, an unknown, all-pervading substance that was postulated by both Newton's dynamics and James Clerk Maxwell's electromagnetism. Mendeleev's ambition was to integrate ether as a chemical element within the periodic system, in order to unify the natural sciences. He also sought to save the individuality and integrity of chemical elements, which were threatened by radioactivity and electrons - the existence of subatomic particles favoured the view that atomic elements were made up of smaller units.

In the name of science, Mendeleev spent his life fighting against 'deviations' or superstitions. For example, he struggled against the fashion among educated people for spiritualism, and set up a commission for investigating mediums at the Russian Physical Society. Mendeleev was also concerned with the public face of science. In the newspapers and in his books, Mendeleev defended the legitimacy and the authority of scientific societies in matters of public opinion. $\mathrm{He}$ acted as an expert, first locally and then at the national level, notably through his work on standardization at the Bureau of Weights and Measures and in his attempt to modernize the calendar.

Gordin portrays Mendeleev as a loyal subject of the Tsar, with conservative ideals, who fought desperately against the disintegration both of the Russian Empire and of chemical elements. He never really separated in his mind the future of Russia from the future of science, and had ambitions to be the Russian Newton.

This highly readable book offers two important lessons for working scientists. First, Mendeleev's career illustrates the interplay between scientific creation and economic, political and educational projects. Second, it may be a consolation to know that such a well known scientist endured an incredible number of failures throughout his life. Notably, his project to isolate ether failed and affected his scientific credibility. His solution theory and his views about the origin of oil were wrong. He also failed to reform the calendar, and his application to the Imperial Academy in St Petersburg was turned down. But above all, his firm belief in the individuality of chemical elements - the firm ground in which the periodic system was rooted - finally crumbled.

Bernadette Bensaude-Vincent is in the Department of Philosophy, Université de Paris X, 92001 Nanterre Cedex, France.

\section{An architectural aside}

The Italian scientific revolution, championed by Galileo in the seventeenth century, shares its roots with the mathematical beauty of Renaissance architecture. Galileo, for example, found that studies by the sixteenth-century master architects Giorgio Vasari and Michelangelo came in handy for computing the height of mountains on the Moon. And the Roman architect Marcus Vitruvius Pollio - whose Ten Books on Architecture (De architectura) is still required reading for architecture students today - drew on the proportions of the human body to scale his buildings, on astronomy for their accurate orientation with respect to the heavens, and, of course, on geometry.

The extensive margins of the first printed version (incunabulum) of the Ten Books on Architecture, in 1486, allowed for hand-written annotations. In 1520, Giovanni Battista Sangallo, a leading figure of sixteenth-century Roman architecture who worked with Raphael on St Peter's Basilica in Rome, filled the margin with annotations and beautiful drawings.

To celebrate its 400th anniversary last year, the Accademia Nazionale dei Lincei, Italy's national academy, has published a high-quality facsimile of this copy of Ten Books on Architecture.The page shown here describes the importance of the orientation of buildings for the health of their inhabitants. In a series of illustrated comments, Sangallo stresses the relevance of this for the Roman climate.

This exquisite book links the genius of
Vitruvius' original text to its first printed edition, to the freshness of Sangallo's notes, and to a contemporary introduction by art historian Ingrid Rowland.

Giovanni F. Bignami

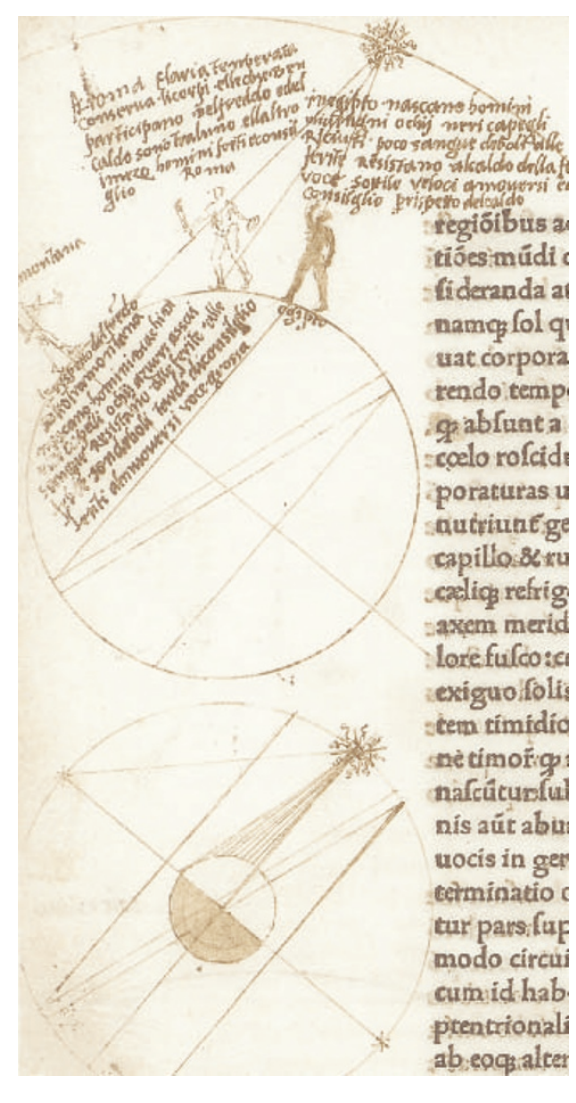

